\title{
Information and Communication Technology to Help Students Create Their Own Books the Dialogic Way
}

\author{
Francisca Maria Ivone \\ francisca.maria.fs@um.ac.id \\ Department of English \\ Universitas Negeri Malang \\ Malang, Indonesia \\ $*$ \\ George M Jacobs \\ george.jacobs@gmail.com \\ International Association for the Study of Cooperation in Education \\ Singapore \\ * \\ Made Hery Santosa \\ mhsantosa@undiksha.ac.id \\ English Language Education Department \\ Universitas Pendidikan Ganesha, \\ Singaraja, Bali, Indonesia
}

\section{Article History \\ Received: $\quad 06 / 30 / 2020$ \\ Reviewed: $\quad 04 / 8 / 2020$ \\ Revised: $\quad 07 / 22 / 2020$ \\ Accepted: $\quad 15 / 8 / 2020$}

Keywords:

Feedback; collaboration; communication; creating books; creativeity; ICT;

interaction; multiliteracies, visual literacy; writing

DOI:

https://doi.org/10.33508/bw.v8i2.2545

\begin{abstract}
The use of Information and Communication Technology (ICT) in language learning allows students to be more engaged and innovative. The present article explores the potential use of technology in the planning, drafting, reviewing, and publishing stages of students' own book creation. First, the use of digital tools to create books in an interactive and engaging process and format is discussed. Then, the varieties of multimedia books created using ICT are explored. Next, the use of technology for sharing ideas, communicating opinions, collaborating, and reviewing others' books is explained. The article also describes some collaborative methods students may employ in creating books. Finally, it discusses learners' development of technology and media literacy in the creation of their own books.
\end{abstract}

\section{Introduction}

Teachers guiding students to create information and communication technology their own books has been practised for many years (Dupuy \& McQuillan, 1997; (ICT) has done and continues to do much that improves and facilitates students' book Mak, Conjam, \& Chan, 2008; Rodgers, creation. The present article suggests areas 1997). Jacobs (2020) discussed various in which ICT can assist students as they advantages of and obstacles to students generate their own books in dialog with creating their own books. Fortunately, 
article include students developing ideas for their books, dialoging and otherwise collaborating with peers, creating text, visuals, and other non-text elements for the books, receiving and responding to peer and teacher feedback on book drafts, and storing and sharing their books. Moreover, students creating their own books with technology also promotes their technology and media literacy.

\section{Empowering Technology-Supported Interaction}

Some researchers worry that modern technologies, such as smartphones, isolate students, as students may put in their earbuds or put on their headphones as a means of cutting themselves off from those around them (McPherson, Smith-Lovin, \& Brashears, 2006). However, Cho (2015) reported an opposite effect. Perhaps, teachers have a role to play in whether students' technology use results in isolation or interaction. Students will be more likely to use technology to interact with peers if teachers help them learn and deploy the collaborative skills needed to interact harmoniously and efficiently when using technology (Johnson, Johnson, \& Holubec, 2007; 2020). Examples of some of the many collaborative skills useful with ICT include encouraging others to participate, asking for help, asking for reasons, thanking and praising others, and pointing out other perspectives.

ICT in support of learning enjoys support from many theories in education, e.g., Social Constructivism (Palincsar, 1997). Social Constructivism has "constructivism" in its name to contrast it which what had been the prevailing theory in Educational Psychology: Behaviorism (Gardner, 1985). Behaviorism sees learning as externally driven; teachers, family members, reading materials, etc. pour information into students' heads just like someone pours water into a glass. Everyone, according to Behaviorism, regardless of age, personality, and even species, learns in this same way. All students who are taught the same information, attitudes, etc. learn that same information, those same attitudes, etc. Constructivism, in contrast, focuses on internal, not external, forces shaping learning. These internal forces reflect the uniqueness of all students; as a result, what students learn will be different, as everyone constructs their own, individual learning.

The word "social" in Social Constructivism highlights that people learn mostly from their interactions with others. In the case of students, these enriching interactions can take place not just with teachers, but with peers as well. Social Constructivism looks not just at cognition thinking, knowledge, and skills - but also at affect - emotions and attitudes - (Niedenthal $\&$ Brauer, 2012). Interactions can not only enhance thinking and bring to the fore pleasant emotions, but the resulting dialog and other forms of collaboration can improve the work students do as they learn, e.g., students can make better books when the books are made as part of a collaborative process, even when each student is responsible for their own book. For instance, the stereotype of artists shows them as solitary people who work alone, whereas in reality, many artists, in areas as diverse as painting and dance, rely on colleagues for guidance. An example is Pablo Picasso who did not consider one of his paintings finished until fellow painter George Braque had given his comments (John-Steiner, 2000).

What tools do students use to do their social construction? Dialog functions as one of the crucial tools (Mercer, Hennessy, \& Warwick, 2019). Dialog need not always 
take the form of face-to-face spoken interaction; it can also be written and visual, as well as taking place over a distance via ICT. It can also be in the form of collaborative tasks and projects. Relevant studies include those that have examined the doing of projects via digital means (Dalim et al., 2019; Özen \& Duran, 2019; González Mesa, 2020), interactivity (Hutchison \& Mitchell, 2009), and animations (Yıldirım \& Torun, 2014). This article will introduce some of the many ICT tools via which students can interact with peers and others. Excitingly, these digital tools are increasing in number, improving in quality, and becoming more widely available, sometimes at lower cost. Some ways that ICT can serve to increase student dialog (spoken, written, and via drawing) in all the areas listed in the previous paragraph will also be discussed.

\section{Creating Books the Dialogic Way Using the Process Approach}

In this section, we will talk about the importance of the process students experience as they create their books.

Nowadays, most teachers advocate that students use the Process Approach (Boas, 2011) in their writing, whether they are writing something 10,000 words long or something 30 words long, something with many visuals or something with no visuals. To understand the Process Approach, it is first necessary to understand the Product Approach, which is a very different way to create. In the Process approach, writers believe they are transferring unchanged what is in their minds onto the paper or the screen. Usually, one draft is thought to be enough to create the final product. The Product Approach is partly based on the inaccurate stereotype of talented writers and artists as people who create their great work with a minimum of preparation, in a linear manner from start to finish without any restarts or changes. At one time, teachers taught students to follow the Product Approach.

However, with the ascendance of cognitive psychology and social cognitivism, researchers investigated what professional writers actually do, and this research suggested that most professional writers do something very different from the Product Approach (Flower \& Hayes, 1981). Furthermore, the research also suggested that same non-linear process also applies to artists in other categories (John-Steiner, 2000). For instance, the researchers found that expert writers often write in recursive phases, not in a linear, consecutive, oneafter-another manner.

Different researchers use different names for these recursive phases in the Process Approach, but here is one set of names for these phases in the writing process and a description of each phase.

a. Idea generating phase - Writers develop ideas about what to write and about how to organize their writing, e.g., will they write a regular book, an audiobook, or a comic book. Ways writers use to generate ideas include reading, watching videos, note taking, talking to others, brainstorming, observing others, and self-reflecting. In this idea generating phase, technologies in such forms as websites, software programs, and mobile applications can assist in these processes. Examples include virtual wall applications (e.g., Padlet, Linoit, Online Stickies), cloud collaborative platforms (e.g., Wakelet, Evernote, Pocket, Google Docs, Google Slides), interactive whiteboard (e.g., Jamboard, Charlala, Whiteboard.fi), and mind map apps (e.g., Mindmeister, Mind Node, Free Map). These technologies aid student writers to research, brainstorm, and take notes collaboratively. Students can also share resources, ideas, and 
notes with each other via websites and mobile apps.

b. Drafting phase - Writers do a draft of what they will write. Sometimes, writers need to do many drafts. Sometimes, before drafting again, they need to go back and generate more ideas. Sometimes their drafts involve not only text but also audio, visuals, and audio-visual formats. When drafting, writers do not worry about surface matters, such as grammar or spelling. Similar to what happens in the idea generation phase, in this drafting phase, writers can employ collaborative writing using virtual wall or collaborative cloud platforms. They can also create visually rich drafts in the form of storyboards using collaborative apps for drawing, such as Jamboard, Charlala, and Whiteboard.fi. The technologies used in this stage should allow students to collaboratively draft in multimedia formats.

c. Editing (for content and organization) phase - In addition to selffeedback, writers can ask others to give them feedback on their drafts, but only on the ideas and the way the ideas are organized, not on surface matters. Students can help each other reorganize their books on collaborative cloud platforms. They can also leave comments or feedback using review features available in word processing and presentation software and apps. Plus, they can edit by annotating any file format using mark-up features that enable them to give comments in the forms of text, audio, and images. They may also suggest suitable illustrations for their peers' books. To do this, students can simply share images through chat applications (e.g., WhatsApp, WeChat, Line, Telegram). The technologies used in this editing stage facilitate students' collaborative drafting in multimedia formats by modifying and annotating each other's digital drafts. d. Proofreading (for surface matters) phase - When writers are happy with the content and organization of their writing (sometimes this requires many phases of idea generating, drafting, and checking for content or organization), they check, and ask others to help them check, for surface matters. Technology may assist student writers in two ways during this stage. First, it can be used a tool for checking spelling, grammar, and diction. Spell and grammar checkers in word processing and presentation software and apps can all serve the purpose of giving instant feedback on spelling and grammatical accuracy. Students can also give such by themselves. Second, technology can also be employed as a medium for collaborating. All of the collaborative apps mentioned in the previous stages can be used to serve this purpose.

e. Publishing - When writers are happy with their books, they can publish them in many forms, printed or non-printed. This stage may not be the ultimate goal of student writers. For instance, they can also publish for the purpose of collecting feedback from others. Thus, they may revise their books even after they are published. There are many outlets for publishing books electronically, e.g., students can publish books on their blogs or other social media networks. They may also circulate them within a limited audience, for instance through class course management systems (CMS), e.g., Edmodo, Google Classroom, Moodle, Canvas, Blackboard, etc.

As noted earlier, the Process Approach is recursive, not linear. "Recursive" means that instead of doing one phase or one part and then never going back to work on that phase or part again, sometimes writers repeat the same phase, perhaps repeating it multiple times. Furthermore, they may make 
many changes to what they are writing, even throwing away or deleting some parts. The proofreading phase comes last among the first four phases in the process, but the other three phases can take place at different times. For example, sometimes writers may think they have finished, but then, they wake up in the morning with an exciting idea to include in their project (Csikszentmihalyi, 1997).

It should come as no surprise that many of the researchers who discovered and explored the Process Approach used a Social Constructivist lens (Slavkov, 2015; Vygotsky, 1978) to look at human thinking, because unlike the Product Approach to writing, the Process Approach offers many opportunities for dialog. For example, in the idea generating phase of the Process Approach, students can develop ideas for their writing by reading what peers have written or by reading books that peers have recommended. Furthermore, students can discuss their writing ideas with peers who can offer supportive ideas. However, being supportive does not always mean that peers only make positive comments. Instead, constructive criticism can point out possible weaknesses. As a Russian proverb states, "An enemy will agree, but a friend will disagree." This dialog can take place as students write their own books or collaborate with others in writing books together. Our argument is that the process book creation should be interactive, meaningful, and emotionally engaging for the students who write the books and for other students who read the books or help in the process of writing the books.

We have given some suggestions about how ICT can aid students' writing process, and we will give some more specific suggestions later in this article. At this point, let us cite some studies suggesting that students creating books with digital tools can promote interaction and emotional engagement (Beach, Clemens, \& Jamsen, 2010; Beetham, McGill, \& Littlejohn, 2009; Carrignton \& Robinson, 2009; Kim, Ng, \& Lim, 2009). Please note that the studies cited in the previous sentence all pre-date 2010; thus, while the use of digital tools is becoming increasingly common, it is by no means a new phenomenon. Digital storytelling is increasingly popular in language learning, and apps used for digital storytelling also promote student-centered, technology-enriched learning environment (Dalim et al., 2019), because they allow stories to be told in more exciting, multimedia ways, with not only texts but also visual images and audio, and even in the form of videos.

\section{Developing Multiliteracies by Creating Multimedia Books}

In this section, we explore some digital book formats that incorporate textual, visual, and audio elements. Multimedia books may take the form of visual books, audiobooks, audio-visual books, and interactive books that make use of Augmented Reality technology. They can be in such forms as picture books, comics, animations, and branching narratives.

Some people feel that visuals are only appropriate in books for young children. With the rise of technology, this view has been rendered outmoded. Yes, the old definition of literacy - being able to read and write and to detect the messages embedded in written texts - now has a companion: visual literacy (International Visual Literacy Association, 2020; Sinatra, 1986; Stankiewicz, 2004). Visual literacy involves being able to read images and to create images. Just as students of all ages, as well as adults not involved in formal 
education, need to be literate in reading and writing texts, so too do we all need to be literate in understanding the images created by others, as well as in creating our own images for ourselves and others. Technology has made image creation so much easier. Furthermore, the advent of video games, YouTube, Instagram, and other visual-predominant forms of communication continues to heighten the importance of visual literacy.

Indeed, modern education seeks to incorporate "multiliteracies" (Cope \& Kalantzis, 2010), i.e., in the $21^{\text {st }}$ century, students need to be literate (able to understand and create) in many modes. Previously, the main mode that mattered was the mode of words, and literacy mostly meant reading (understanding words) and writing (creating words for others to understand). Other overlapping literacies include video literacy, musical literacy, game literacy, health literacy, critical literacy, and emotional literacy.

Multiliteracies fits with concept of Multiple Intelligences (Armstrong, 2018), the idea that humans are smart in many different ways, and for education to be both effective and equitable, all intelligences should be deployed to help students learn and to assess their learning. These intelligences include not just

\section{Employing Technologies}

The use of technology for sharing ideas, communicating opinions, collaborating, and reviewing others' books is explained in this section. The section presents examples of current technologies that can be used to facilitate students interacting among themselves and with their teachers, creating the kind of multimedia books proposed in the previous section, giving peer and teacher feedback to book creators, and publishing their own books. verbal/linguistic intelligences, which focus on ability with words, i.e., the traditional view of literacy, but also intelligences that have more recently been given more attention, e.g., musical/rhythmic intelligences, bodily/kinesthetic intelligences, inter- and intrapersonal intelligences, and logical/mathematical intelligences. We see these changes in literacies and intelligences reflected in children's books. For example, some children's books include touch, e.g., books about rabbits with imitation rabbit fur, and pop-up books that provide threedimensional experiences.

With all these modalities, students have more ways to learn and more ways to create; they can share more completely what is in their minds and what they are creating as the engage in various modes. All these options fit with the spirit of these times in which people are taking more control of their experiences. For instance, instead of listening only to the music available on a small number of radio stations, people make their own playlists, and instead of selecting a movie or tv shows and then watching it till the end, an end chosen by the producers, people play games in which they have a major role in determining how the story develops and ends.

Technological tools, including new ones, to be utilized for digital story creations vary in features from accommodating static to interactive reading, from review to creation and publication of books. Websites for reading abound. For instance, Let's Read Asia (https://reader.letsreadasia.org/) provides thousands of free digital stories for children. The stories come from Asian perspectives and cultures, with varieties of languages and art canvas-based illustrations, 
making them rich and compelling. Room to Read (https://literacycloud.org) has various stories from around the world which are accompanied by supplementary materials, e.g., videos, selected reading lists, and other resources for the readers. The stories include colours and illustrations. The materials come with indications of reading level, thereby assisting readers in finding the materials most comfortable for themselves. Story Weaver (https://storyweaver.org.in) is another worthwhile digital story platform. Besides having thousands of completed stories, the platform allows digital story creation by its readers. Authors just need to provide a storyline, because illustrations are provided within the system. The use of levels is also employed here, both for reading and authoring story books. In addition, stories can also be presented in the form of videos. One example of a website with video stories is

Storyline

Online

(https://www.storylineonline.net/). The website by SAG-AFTRA Foundation streams videos featuring celebrated actors reading children's books in creative, interactive, and emotionally compelling ways.

In terms of illustration-making, some other web-based and non-web-based platforms exist to assist the process of creating digital stories. Storybird, for instance, provides collections of illustrations in a wide variety of themes, but it does not allow authors to use their own illustrations. On the other hand, Story Jumper gives story creators opportunities to use their own illustrations. Some image-based platforms, such as Bitmoji and Avatar Creator, can also help with the creation of characters (humans, animals, and even aliens) to illustrate student-created stories. Photoshop and other vector graphic software are available to those who are capable of editing and creating more sophisticated characters and supporting images for their digital stories. Non-copyrighted image providers, e.g., Freepik, FreeVector, VectorStock, and Pin Clipart, are also handy for writing digital stories or books, as they allow writers to use relevant images and illustrations at no charge. Table 1 lists some of the affordances mentioned in this article.

Table 1.

Technologies for interacting, creating, reviewing, and publishing books

\begin{tabular}{|c|c|c|}
\hline Resources for Creating Digital Stories & Free/Paid & What You Can Do \\
\hline $\begin{array}{l}\text { Let's Read Asia } \\
\text { https://reader.letsreadasia.org/ }\end{array}$ & Free & 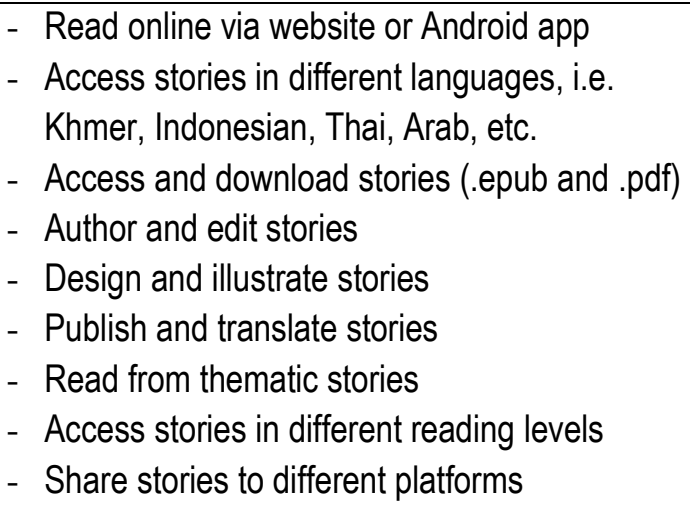 \\
\hline $\begin{array}{l}\text { Literacy Cloud } \\
\text { https://literacycloud.org/ }\end{array}$ & Free & $\begin{array}{l}\text { - } \text { Read online via website } \\
\text { - Save stories for a personal library } \\
\text { - } \text { Favourite stories for further reading } \\
\text { - Download stories } \\
\text { - }\end{array}$ \\
\hline
\end{tabular}




\begin{tabular}{|c|c|c|}
\hline & & $\begin{array}{l}\text { - Access different theme categories } \\
\text { - Access video-based narrated stories } \\
\text { - Download video-based narrated stories } \\
\text { - } \text { Read aloud stories } \\
\text { - Share the stories to different platforms }\end{array}$ \\
\hline $\begin{array}{l}\text { Story Weaver } \\
\text { https://storyweaver.org.in/ }\end{array}$ & Free & $\begin{array}{l}\text { - Read stories via website } \\
\text { - Read along stories } \\
\text { - Access different themes } \\
\text { - Access different reading levels } \\
\text { - Access free image stocks } \\
\text { - Access its unique reading programme for } \\
\text { various key highlights, like Easy-to-Use and } \\
\text { Not Dependent to Internet in different readers' } \\
\text { levels } \\
\text { - Translate stories } \\
\text { - Use any images from illustrators in the website } \\
\text { - Create our own stories using its story template } \\
\text { - Publish stories in the website }\end{array}$ \\
\hline $\begin{array}{l}\text { Story Jumper } \\
\text { https://www.storyjumper.com/ }\end{array}$ & $\begin{array}{l}\text { Free and } \\
\text { Paid }\end{array}$ & $\begin{array}{l}\text { - Read existing stories via website } \\
\text { - Create stories using the template } \\
\text { - Use existing illustrations, background, and } \\
\text { characters } \\
\text { - Use illustrations and characters from author's } \\
\text { own creation or non-copyrighted resources } \\
\text { - Create classes for reading stories } \\
\text { - Import classes from Google Classroom } \\
\text { - Publish stories } \\
\text { - Print stories on demand with various prices. }\end{array}$ \\
\hline $\begin{array}{l}\text { Storybird } \\
\text { https://storybird.com/ } \\
\end{array}$ & $\begin{array}{l}\text { Free and } \\
\text { Paid }\end{array}$ & $\begin{array}{l}\text { - } \text { Read available stories from the website } \\
\text { - Create various types of story formats - picture } \\
\text { book, longform story, flash fiction, comic, and } \\
\text { poetry - using the templates given } \\
\text { - } \text { Access freely for } 7 \text { day only } \\
\text { - Involve parents in educators' classes } \\
\text { - } \quad \text { Take various reading activities }\end{array}$ \\
\hline $\begin{array}{l}\text { Freepik } \\
\text { https://www.freepik.com/ } \\
\text { Free Vector } \\
\text { https://www.freevector.com/ } \\
\text { Vector Stock } \\
\text { https://www.vectorstock.com/royalty-free- } \\
\text { vectors } \\
\text { Pin Clipart } \\
\text { https://www.pinclipart.com/ }\end{array}$ & Free & $\begin{array}{l}\text { - Access non-copyrighted images, illustrations, } \\
\text { or figures } \\
\text { - Download non-copyrighted images, } \\
\text { illustrations, or figures by acknowledging the } \\
\text { authors }\end{array}$ \\
\hline $\begin{array}{l}\text { Bitmoji } \\
\text { https://www.bitmoji.com/ }\end{array}$ & Free & $\begin{array}{l}\text { - Create personalised characters in cartoon } \\
\text { mode } \\
\text { - Download personalised characters }\end{array}$ \\
\hline
\end{tabular}

BEYOND WORDS Vol. 8, No. 2, November 2020 Graduate School, Widya Mandala Catholic University Surabaya 


\begin{tabular}{|c|c|c|}
\hline $\begin{array}{l}\text { Canva } \\
\text { https://www.canva.com/templates/search/s } \\
\text { toryboards/ } \\
\text { https://www.canva.com/templates/?query= } \\
\text { comic }\end{array}$ & $\begin{array}{l}\text { Free and } \\
\text { Paid }\end{array}$ & $\begin{array}{l}\text { - Access free images and templates for creating } \\
\text { storyboards and comics } \\
\text { - Download and print storyboards and comics }\end{array}$ \\
\hline $\begin{array}{l}\text { makebeliefscomix } \\
\text { https://www.makebeliefscomix.com/ }\end{array}$ & Free & $\begin{array}{l}\text { - } \text { Creating comic strips from pre-prepared } \\
\text { background and characters } \\
\text { - } \text { Print comic strips }\end{array}$ \\
\hline $\begin{array}{l}\text { Pixton } \\
\text { https://www.pixton.com }\end{array}$ & $\begin{array}{l}\text { Free and } \\
\text { Paid }\end{array}$ & $\begin{array}{l}\text { - Access free images and templates for creating } \\
\text { comics } \\
\text { - Download and print comics }\end{array}$ \\
\hline $\begin{array}{l}\text { Masterpiece Generator } \\
\text { https://masterpiece-generator.org.uk/ } \\
\text { Plot Generator } \\
\text { https://www.plot-generator.org.uk/ }\end{array}$ & Free & $\begin{array}{l}\text { - } \text { Create plots } \\
\text { - } \text { Create characters } \\
\text { - } \text { Create names } \\
\text { - } \text { Create different story genres }\end{array}$ \\
\hline
\end{tabular}

\section{Cultivating Creativity and Relevance}

According to Ulu (2019), originality is one important dimension of the creative writing process. However, McCormick (2015) questioned whether originality is always essential, even for Arts students. Nonetheless, students should feel free to be original, at the same time that quality in all spheres of book production is promoted. Scaffolded activities framed within a project-based learning approach utilizing process and technological supports can be one way of assisting students' digital story creation.

The technologies listed in Table 1 are only some of the tools for digital story creation. The process of cultivating originality of ideas, themes, characters, plots, settings, and supporting elements, including colours, size, and concepts should be emphasized to ensure authenticity of writers' creations. Since story characters do not have to be human, creators can also use objects, animals, and buildings they are familiar with as their characters. They can reinvent themes, plots, settings, and additional elements in their stories. Allowing students to connect to what is familiar to them encourages being observant, critical, and creative. Students can also be authentic in their stories, because different people perceive things differently and experience different events in life. Encouraging student writers to research before writing and re-research during writing is also a good practice during their book writing process. It is also necessary to teach them to be critical and reflective by asking each other questions such as:

- Will the story be interesting to readers?

- Will anything in the story be fun for readers?

- Will readers learn anything from the story?

- Will the story (words and visuals) be understandable to readers?

- Will the visuals be attractive to readers?

- Is there a problem that the main character(s) have to confront in the story?

- Is the problem resolved at the end of the story?

- Is there anything in the story that might make any readers uncomfortable? For example, vegetarian readers may feel 
uncomfortable if people eat meat in the book.

- Is there a cover with the title of the story, the author(s)' and illustrator(s) names?

- Are all the pages numbered?

- Are the illustrations consistent? For example, if the cat is brown on the second page, is the same cat yellow on the fourth page?

These questions can be answered in collaboration with other students during the editing phase of writing in which creators rethink the content and organization of their stories. This editing practice teaches students to not only take learn from sources but also be critical and reflective. Moreover, making students aware of copyright and plagiarism issues is also important. Everyone should learn that there are things which they can take and use for free, but there are many others that belong to other people.

Some students may be able to write a $100 \%$ authentic book, but most students, for the first one or two books, will need to lean on examples of previous works. Thus, their creation may not be $100 \%$ original. Instead, their books may be modifications of previous works. In this section, we will also talk about Artificial Intelligence (AI) technology that may hinder or assist students in creating their own books. The underlying principles of the following methods are collaboration between writers and employment of technology to facilitate collaboration as well as book creation.

Students may start creating books from scratch but they may need some help along the way. They need to think about such matters as the characters, setting, and plot of their stories. AI-injected websites, such as Masterpiece Generator (https://masterpiecegenerator.org.uk/), can help them do these tasks. Students can then discuss what was generated by the websites and decide what to use in their books, i.e., what the websites generate are only possibilities; the final decisions are up to the students.

Book writing may also start from researching previous works. In fact, students can be encouraged to write a book which is inspired by previous works. What is interesting is that the previous works do not even have to be in the form of books. If many film makers can make movies based on someone's life or a bestselling novel, students can certainly write books inspired by biographies, movies, comics, stories told by their parents or friends, and many other works. For instance, they can read book series and write books to continue a series. Students can also transform previous works into a different book format, for instance, from a novel into comic strips, or from a movie to a short story. Another possible way of creating books is by simplifying previous works. Simplification can take the form of reducing the number of main and supporting characters, eliminating less important details and events, or summarizing parts of plots. Students can add illustrations to a story, shorten its length, and simplify the language used in the story.

Book writing offers a way of personalising reading, listening, and viewing experiences. These experiences may occur within the context of students' first, second, or foreign languages. When students read, listen, and view, they form their own interpretations, preferences, and expectations. For instance, people might discuss movies they watch and question why the ending is not a happy one or why the main character ends up marrying the 'wrong' guy. Therefore, when students write their own books in the target language, they do not need to start from scratch. They 
can modify the beginning, the middle, or the ending of a story they have read, listened to, or watched before. They can rearrange the events and change some of the details. They can introduce a new character, omit a character, replace a character or change the personality of the characters. They can also rewrite the story from the point of view of one specific character.

Still another interesting way of writing is by using gamification to create interactive story telling content using a narrative branching structure. Branching narratives, so called because their structure resembles branches in a tree (Berger, 2020), are structures that allow readers to shape their own story from a number of possible storylines. This gives readers the opportunity to determine the trajectories of stories. Readers are directed to a particular scene as a consequence of the choices that have been made. Students can work together on the same story, and they build in several 'intersections' at which the readers take part in the story as characters who need to make a decision at each intersection. The decision can be as trivial as deciding what is for lunch or as important as choosing someone to marry. Student writers can compile the different 'versions' of the story and create a digital story with 'branches' of different possible con-sequences that may happen when the one character makes a decision. When stories are presented in digital form, readers can just click on hyperlinks or pictures that will take them to different plots.

\section{Fostering Technology and Media Literacy Development}

Two approaches to guiding students' development of skills and attitudes are to: (1) teach the necessary skills and attitudes before students embark on tasks; and (2) teach the skills and attitudes as students are doing tasks. We have usually employed the second approach, as we find that instruction in skills and attitudes resonates better with students when they can immediately see the usefulness of what we are teaching (Koda, 2018). For example, students may appreciate the importance of communication skills, e.g., asking for assistance and giving reasons when teaching others, when they are in the midst of communicating with classmates about the books they are creating. Similarly, students will value the importance of technology in language learning when they are able to use it during language learning.

Students need to have sufficient technology and media literacy to be able to create their own digital books. A study by Decat et al. (2019) suggested that technology provides a new modality of learning representation that allows students to learn and to show what they have learned, especially in the contest of young learners. Yamaç and Ulusoy (2016) also found that the use of technology assisted students in understanding elements of digital story books while at the same time enabling them to process ideas for story creations. It is worth noting that when technology is used in the creation of multimedia books, students will not only grow their technology and media literacy but also their writing ability.

Despite of the positive support of technologies in students' learning of media literacy and in creation of digital storybooks, Talaee and Noroozi (2019) pointed out that it is still very important to look at the students' digital divide in the era of saturated access to technology. The digital divide may handicap students' performance in the use of technologies in the teaching and learning process. Some students are technology experts, but many 
use ICT only for communicating on social media. Thus, teachers should consider training their students, starting with the simplest technology available for creating their own books. In addition, teachers may need to train students to use various technologies to support communication and collaboration among them.

\section{Conclusion}

Book writing is worthwhile adventure on students' language learning journey. The experience will not only lead them to produce comprehensible output but also take them on meaningful language learning paths in which reading is an essential part, collaboration is indispensable, and technology is a tool and medium of creation. There are soft skills that students will learn on their collaborative book writing mission, i.e., creativity, critical thinking, communication, and collaboration. There are also multiliteracies to be polished along the way, such as media literacy and technology literacy.
Many technologies have been introduced and explored in this article, but it should be kept in mind that it is not the technology that defines the success of language learning; it is how the technology is used to support language learning and thinking skills. Technology provides students and teachers many avenues for writing books the dialogic way. Some educators may argue that we can at any point omit technology from language teaching and learning, but the future predicts that we will rely more and more on technology, especially during emergency times such as the COVID-19 pandemic that struck in 2020.

\section{(C) Francisca Maria Ivone, George M. Jacobs \& Made Hery Santosa}

Francisca Maria Ivone teaches at the Department of English, Universitas Negeri Malang. Her areas of expertise and interests are ELT, TELL, CALL, Extensive Listening and Viewing, ER, learning autonomy, and collaborative learning. She gives training to preservice and in-service teachers on the use of technology in language teaching and learning.

George M Jacobs teaches and writes on a variety of seemingly disparate but actually closely related topics ranging from education to health to cooperation to paradigm shift. His current writing projects include a book to be titled 'Being a Community Engage Educator' and a MOOC on Extensive Reading.

Made Hery Santosa is a lecturer at Universitas Pendidikan Ganesha, Bali, Indonesia. He publishes and reviews works on EFL, CALL, E-Learning, Innovative Pedagogies, Learning Technologies, Learner Autonomy, and Learning Approaches. He has been extensively speaking in various TESOL forums and workshops for Indonesian teachers and headmasters.

\section{References}

Armstrong, T. (2018). Multiple intelligences in the classroom $\left(4^{\text {th }}\right.$ ed.). Alexandria, VA: Association for Supervision and Curriculum Development.

Beach, R., Clemens, L., \& Jamsen, K. (2010). Digital tools: Assessing digital communication and providing feedback to student writers. In A. Burke \& R. F. Hammett (Eds.), Assessing New Literacies: Perspectives from the Classroom (pp. 157-176). Peter Lang.

Beetham, H., McGill, L., \& Littlejohn, A. (2009). Thriving in the 21st century: 
Report of the learning literacies in a digital age project. JISC

Berger, R. (2020). Dramatic Storytelling \& Narrative Design. Boca Raton: CRC Press,

https://doi.org/10.1201/9780429453779

Boas, I. V. (2011). Process writing and the Internet: Blogs and Ning networks in the classroom. English Teaching Forum, 49(2), 26-33. ERIC Document Reproduction Service No. EJ962381

Carrington, V. \& Robinson, M. (Eds.) (2009). Digital literacies: Social learning and classroom practices London: SAGE Publications Ltd. doi: 10.4135/9781446288238

Cho, J. (2015). Roles of smartphone app used in improving social capital and reducing social isolation.

Cyberpsychology, Behavior, and Social Networking, 18(6), 350-355.

Cope, B., \& Kalantzis, M. (2009). "Multiliteracies": New literacies, new learning. Pedagogies: An International Journal, 4(3), 164-195.

Csikszentmihalyi, M. (1997). Creativity: Flow and the psychology of discovery and invention. HarperCollins Publishers.

Dalim, S. F., Azliza, N. Z. M., Ibrahim, N., Zulkipli, Z. A., \& Yusof, M. M. M. (2019). Digital storytelling for 21st century learning: A study on preservice teachers' perception. Asian Journal of University Education, 15(3), 226-234.

Decat, E., Damjanovic, V., Branson, S., Blank, J., \& Berson, I. (2019). Using Touch Technology to Foster Storytelling in the Preschool Classroom. 10(2), 1-22.

Dupuy, B., \& McQuillan, J. (1997). Handcrafted books: Two for the price of one. In G. M. Jacobs, C. Davis, \& W. A. Renandya (Eds.). Successful strategies for extensive reading (pp. 171-180). SEAMEO Regional Language Centre.

Flower, L., \& Hayes, J. R. (1981). Plans that guide the composing process. Writing:
The Nature, Development, and Teaching of Written Communication, 2, 39-58.

Gardner, H. (1985). The mind's new science: A history of the cognitive revolution. Basic Books.

González Mesa, P. A. (2020). Digital Storytelling: Boosting Literacy Practices in Students at A1-Level. HOW, 27(1), 83-104. https://doi.org/10.19183/how.27.1.505

Hutchison, D., \& Mitchell, J. C. (2009). Interactive Storytelling - Second Joint International Conference on Interactive Digital Storytelling, ICIDS 2009, Proceedings. In Lecture Notes in Computer Science (including subseries Lecture Notes in Artificial Intelligence and Lecture Notes in Bioinformatics): Vol. 5915 LNCS.

International Visual Literacy Association. (2020). Visual Literacy Today. Retrieved from https://visualliteracy today. org/about/

Jacobs, G. M. (2020). Helping students create their own books the dialogic way. Beyond Words, 8(1), 1-9. Retrieved from http://journal.wima.ac.id/index. $\mathrm{php} / \mathrm{BW} / \mathrm{article} / \mathrm{view} / 2354$

John-Steiner, V. (2000). Creative collaboration. Oxford University Press.

Johnson, D. W., Johnson, R. T., \& Holubec, E. (2020). Common mistakes in using cooperative learning - and what to do about them? The newsletter of the Cooperative Learning Institute, 34(1), 3-4.

Johnson, D. W., Johnson, R. T., \& Holubec, E. J. (2007). Nuts \& bolts of cooperative learning ( $2^{\text {nd }}$ ed.). Edina, $\mathrm{MN}$ : Interaction Book Company.

Kim, P., Ng, C. K., \& Lim, G. (2010). When cloud computing meeting with Semantic Web: A new design for eportfolio systems in the social media era. British Journal of Educational Technology, 41, 1018-1028. doi:10.1111/j.1467-8535. 2010.01055.x 
Koda, K. (2018). Integrated communication skills approach: Reading to learn as a basis for language and content integration. In K. Koda, \& J. Yamashita (Eds.), Reading to Learn in a Foreign Language (pp. 30-54). Routledge.

Mak, B., Coniam, D., \& Chan, M. S. K. (2008). A buddy reading programme in Hong Kong schools. ELT Journal, 62(4), 385-394.

McCormick, A. (2015). How important is originality in the art room? https://theartofeducation.edu/2015/09/2 5/how-important-is-originality-in-theart-room/

McPherson, M., Smith-Lovin, L., \& Brashears, M. E. (2006). Social isolation in America: Changes in core discussion networks over two

Palincsar, A. S. (1998). Social constructivistperspectives on teaching and learning Annual Review of Psychology, 49, 345-375Rodgers, T. (1997). Partnerships in reading and writing. In G. M. Jacobs, C. Davis, C., \& W. A. Renandya (Eds.). Successful strategies for extensive reading (pp. 120-127). SEAMEO Regional Language Centre.

Sinatra, R. (1986). Visual literacy connections to thinking, reading and writing. Springfield, IL: Charles C. Thomas Publisher.

Slavkov, N. (2015). Sociocultural Theory, the L2 writing process, and Google Drive: Strange bedfellows? TESL Canada Journal, 32(2), 80-94. Retrieved from https://files.eric.ed.gov/fulltext/EJ1083 966.pdf decades. American

Sociological

Review, 71(3), 353-375

Mercer, N., Hennessy, S., \& Warwick, P. (2019). Dialogue, thinking together and digital technology in the classroom: Some educational implications of a continuing line of quiry. International Journal of Educational Research,97, 187-199.

Niedenthal, P. M., \& Brauer, M. (2012). Social functionality of human emotion. Annual Review of Psychology, 63, 259-285.

Özen, N. E., \& Duran, E. (2019). Digital Storytelling in Secondary School Turkish Courses in Turkey. International Journal of Education and Literacy Studies, 7(4), 169. https://doi.org/10.7575/aiac.ijels.v.7n.4 p.169

Stankiewicz, M. A. (2004). Notions of technology and visual literacy. Studies in Art Education, 46(1), 88-91.

Talaee, E., \& Noroozi, O. (2019). ReConceptualization of "Digital Divide" among Primary School Children in an Era of Saturated Access to Technology. 12(1),27-35. 10.26822/iejee.2019155334

Ulu, H. (2019). Investigation of fourth grade primary school students' creative writing and story elements in narrative text writing skills. International Journal of Progressive Education, 15(5), 273-287. https://doi.org/10.29329/ijpe.2019.212. $\underline{18}$

Vygotsky, L. S. (1978). Mind in society: The development of higher psychological processes (M. Cole, V. John-Steiner, S. Scribner, \& E. Souberman, Eds). Cambridge, MA: Harvard University Press. 